\title{
DEATH OF DR. VAN STRAELEN
}

$T^{T}$ is with deep regret that we learn as we go to press of the death of Dr. Victor van Straelen, of Belgium, president of the National Parks Institute of the Congo and a vice-president of the FPS since April, 1955. Dr. van Straelen was in England last October, when he came over specially for the ceremony at St. Katherine Dock of the commissioning of the Beagle, the ship for the research station of the Charles Darwin Foundation of the Galapagos, of which he was president. He had just returned from the international scientific project in the Galapagos and the dedication of the research station when he died. An appreciation of Dr. van Straelen will appear in the next issue of ORYX.

\section{The Diamond Jubilee}

\author{
By C. R. S. PITMAN
}

7 HE Society celebrated its Diamond Jubilee on 16th December, 1963, with a dinner, attended by 134 members and their guests, in the Fellows' Restaurant of the Zoological Society of London. What has happened during these sixty years? What does the future hold for the world's wild life? Much has been accomplished, but there is much to be done. Achievements innumerable are recorded in the pages of ORYX, and in the fournal which preceded it. Referring to the Society, a Special Correspondent wrote in The Times recently, "Throughout the years one organisation (and for many years one alone) has sought to guide governments through conflicts caused by the rival claims of land developers, hunters, zoologists, and humanitarians." Here in a nutshell are the Society's aims and problems. Over these sixty years man, the archdestroyer, has demonstrated the evil of which he is capable, and millions of wild animals, particularly in Africa, have perished. Sad reading indeed, but there is yet hope for the future, albeit the vicissitudes are many; we must safeguard what is left.

The Society's jubilee seems a fitting occasion to pay special tribute to Miss Kathleen Clarke, the Society's Assistant Secretary, for her thirty-five years long and devoted service, and to thank her most gratefully for all she has done, always so willingly and efficiently.

\section{Retirement of the Secretary}

This issue of ORYX ushers in a new era for the Society, when we welcome Mr. Richard Fitter as Honorary Secretary and Mrs. M. S. Fitter as Editor of ORYX, in the place of Lt.-Col. C. L. Boyle, who relinquishes these offices after fourteen arduous and eventful years. The Society's seventh Secretary, he was utterly dedicated and selfless, above all indefatigable and enthusiastic, and it is not overstating the case to claim that there are many species of wild animals now enjoying a better prospect of survival thanks to his zeal and unremitting efforts. Latterly, for several years he has been Chairman of the Survival Service of the International Union for Conservation of Nature. His expertise and the extent of his knowledge of wild life 
are amply demonstrated in the high standard of ORYX and the multifarious subjects with which it deals. He has been the architect of many a successful conservation project, the best known being "Operation Noah" and "Operation Oryx". During his tenure of office he has witnessed farreaching changes in the set-up of the forces of conservation which have had an impact, at times frustrating, on the activities of the Society. No better person could have been found to further the good work of Edward North Buxton, Geoffrey Dent, Geoffrey Vevers, J. Stevenson-Hamilton, C. W. Hobley, and H. G. Maurice, and the award of the O.B.E. was well deserved recognition of his valuable services. In taking farewell of one who has served the Society so conscientiously and well and in thanking him most gratefully for all he has done, we also express our appreciation and gratitude for the unassuming and willing help and constant encouragement he has always had from his wife.

\section{IUCN Nairobi, 1963}

By R. S. R. FITTER

TWO striking statements highlighted the underlying theme of the Eighth General Assembly and Ninth Technical Meeting of the International Union for Conservation of Nature and Natural Resources held at Nairobi, Kenya, from 12th to 24th September, 1963. Stuart Udall, United States Secretary of the Interior, described the world wildlife situation as a race between conservation and catastrophe. Sir Julian Huxley, doyen of world conservationists and a Vice-President of the Fauna Preservation Society, declared boldly that man is in danger of becoming the cancer of his own planet, instead of its lord and master, or better still its benevolent guide. The Assembly was attended on behalf of the Fauna Preservation Society by Lt.-Col. C. L. Boyle, the Secretary, accompanied by Mrs. Boyle, and by Mr. R. S. R. Fitter, Secretary designate, and Mrs. M. S. Fitter, Editor designate of ORYX. Other members of Council who were present were Dr. Fraser Darling, Sir Hugh Elliott, and Mr. Peter Scott. The first presentation of the J. C. Phillips Medal for distinguished service to international wildlife conservation since the previous General Assembly was made to Mr. E. M. Nicholson, Director-General of the Nature Conservancy.

The subjects discussed at the Technical Meeting were arranged under the general heading of " The ecology of man in the tropical environment ". At the end of the Assembly, Professor François Bourlière (France) succeeded Professor Jean Baer (Switzerland) as President of the Union, and Mr. van der Elst (Belgium), Dr. Shawki (Sudan), and Dr. E. B. Worthington (U.K.) became Vice-Presidents. Among the forty resolutions passed were one calling for a conference in 1965 on animals and plants threatened with extinction; one calling for the strict protection of the lowland gorilla in at least one national park in each country of West Africa where it is found; one calling for the preservation of the red colobus monkey and Livingstone's antelope in Zanzibar ; one urging the Governments of Indonesia and Malaysia to implement the legislation that protects 